\title{
Seasonal Influence on the Risk of Relapse at a Rise of Antineutrophil Cytoplasmic Antibodies in Vasculitis Patients with Renal Involvement
}

Citation for published version (APA):

Kemna, M. J., Tervaert, J. W. C., Broen, K., Timmermans, S. A. M. E. G., van Paassen, P., \&

Damoiseaux, J. G. M. C. (2017). Seasonal Influence on the Risk of Relapse at a Rise of Antineutrophil Cytoplasmic Antibodies in Vasculitis Patients with Renal Involvement. Journal of Rheumatology, 44(4), 473-481. https://doi.org/10.3899/jrheum.160066

Document status and date:

Published: 01/04/2017

DOI:

10.3899/jrheum.160066

Document Version:

Publisher's PDF, also known as Version of record

\section{Document license:}

Taverne

Please check the document version of this publication:

- A submitted manuscript is the version of the article upon submission and before peer-review. There can be important differences between the submitted version and the official published version of record.

People interested in the research are advised to contact the author for the final version of the publication, or visit the DOI to the publisher's website.

- The final author version and the galley proof are versions of the publication after peer review.

- The final published version features the final layout of the paper including the volume, issue and page numbers.

Link to publication

\footnotetext{
General rights rights.

- You may freely distribute the URL identifying the publication in the public portal. please follow below link for the End User Agreement:

www.umlib.nl/taverne-license

Take down policy

If you believe that this document breaches copyright please contact us at:

repository@maastrichtuniversity.nl

providing details and we will investigate your claim.
}

Copyright and moral rights for the publications made accessible in the public portal are retained by the authors and/or other copyright owners and it is a condition of accessing publications that users recognise and abide by the legal requirements associated with these

- Users may download and print one copy of any publication from the public portal for the purpose of private study or research.

- You may not further distribute the material or use it for any profit-making activity or commercial gain

If the publication is distributed under the terms of Article $25 \mathrm{fa}$ of the Dutch Copyright Act, indicated by the "Taverne" license above, 


\title{
Seasonal Influence on the Risk of Relapse at a Rise of Antineutrophil Cytoplasmic Antibodies in Vasculitis Patients with Renal Involvement
}

\author{
Michael J. Kemna, Jan Willem Cohen Tervaert, Kelly Broen, Sjoerd A.M.E.G. Timmermans, \\ Pieter van Paassen, and Jan G.M.C. Damoiseaux
}

ABSTRACT. Objective. The objective of this study was to identify risk factors for a relapse at the time of an increase in antineutrophil cytoplasmic antibodies (ANCA) in patients with renal ANCA-associated vasculitis (AAV).

Methods. All patients between January 2000 and November 2011 with renal AAV having an ANCA rise during remission were included. Differences in time to relapse since the ANCA rise were assessed using a Cox regression model. The level of 25-hydroxy Vitamin D (25(OH)D) was assessed at the ANCA rise and at a subsequent relapse or time-matched during remission.

Results. Sixty patients had an ANCA rise, of whom 36 patients relapsed. Three risk factors were associated with a relapse at the time of the ANCA increase: previous disease activity not treated with cyclophosphamide or rituximab (HR 3.48, 95\% CI 1.60-7.59), an ANCA rise during the fall season (HR 4.37, 95\% CI 1.60-11.90), and an extended ANCA rise (HR 3.57, 95\% CI 1.50-8.48). Levels of $25(\mathrm{OH}) \mathrm{D}$ significantly decreased during followup in relapsing patients, but not in patients who remained in remission (difference $-6.3 \pm 14.4, \mathrm{p}=0.017$ vs $2.7 \pm 16.3, \mathrm{p}=0.430$ ).

Conclusion. ANCA rises occurring during the fall season are more frequently followed by a relapse than ANCA rises occurring during other seasons. Although it is tempting to speculate that decreasing Vitamin D levels following the ANCA rise can be held responsible for the subsequent relapse, this remains to be determined. (First Release February 15 2017; J Rheumatol 2017;44:473-81; doi:10.3899/jrheum.160066)

Key Indexing Terms: ANTINEUTROPHIL CYTOPLASMIC ANTIBODIES ANCA-ASSOCIATED VASCULITIS GRANULOMATOSIS WITH POLYANGIITIS SEASON VITAMIN D FOLLOWUPSTUDY

Antineutrophil cytoplasmic antibodies (ANCA) are involved in the pathophysiology of ANCA-associated vasculitis

From the Cardiovascular Research Institute Maastricht (CARIM), Maastricht University; Department of Internal Medicine, Division of Nephrology and Clinical Immunology, Maastricht University Medical Center; Central Diagnostic Laboratory, Maastricht University Medical Center, Maastricht; Noordoever Academy, Sint Franciscus Gasthuis, Rotterdam; Department of Clinical Chemistry and Hematology, Zuyderland Medical Center, Sittard-Geleen, the Netherlands.

M.J. Kemna has received the Kolff Student Researcher grant from the Nierstichting.

M.J. Kemna, MD, CARIM, Maastricht University, and Department of Internal Medicine, Division of Nephrology and Clinical Immunology, Maastricht University Medical Center; J.W. Cohen Tervaert, MD, PhD, CARIM, Maastricht University, and Noordoever Academy, Sint Franciscus Gasthuis; K. Broen, MSc, PhD, Department of Clinical Chemistry and Hematology, Zuyderland Medical Center; S.A. Timmermans, MD, CARIM, Maastricht University, and Department of Internal Medicine, Division of Nephrology and Clinical Immunology, Maastricht University Medical Center; P. van Paassen, MD, PhD, Department of Internal Medicine, Division of Nephrology and Clinical Immunology, Maastricht University Medical Center; J.G. Damoiseaux, MSc, PhD, Central Diagnostic Laboratory, Maastricht University Medical Center.

Address correspondence to Dr. J. Damoiseaux, Maastricht UMC+, Centraal Diagnostisch Laboratorium, Postbus 5800, 6202 AZ Maastricht. the Netherlands.E-mail: jan.damoiseaux@mumc.nl

Accepted for publication December 23, 2016.
$(\mathrm{AAV})^{1}$. The use of an ANCA rise to predict relapses, however, is a subject for debate $2,3,4,5,6$. An ANCA rise has previously been used to guide preemptive immunosuppressive treatment to prevent a relapse ${ }^{4}$. But the use of such a strategy raises concerns over unnecessary exposure to treatment-related side effects, because only a proportion of patients develop a relapse after an ANCA rise $3,4,5,6,7,8$. Previously, we have shown that ANCA rises are associated with relapses in patients with renal involvement, but not in patients with nonrenal disease ${ }^{8}$. In our current study, we further elaborated on potential risk factors. Hereto, we include only patients with renal involvement who have an ANCA rise during remission.

Patients with renal involvement are nearly always ANCA-positive, whereas a positive ANCA titer is less often found in patients with nonrenal disease ${ }^{9}$. From our experience, the presence of ANCA seems necessary for severe disease activity, because all patients were ANCA-positive at the time of a major relapse ${ }^{8}$. Major relapses can still occur when patients are ANCA-negative, however ${ }^{6,10}$, and a small subgroup of patients with pauciimmune glomerulonephritis are ANCA-negative ${ }^{11}$. Yet not every ANCA rise leads to disease reactivation; many rises are

Personal non-commercial use only. The Journal of Rheumatology Copyright @ 2017 . All rights reserved. 
not followed by a relapse. We hypothesize that a "second hit" may be required to create a proinflammatory environment that enables the ANCA to become pathogenic. In the second-hit hypothesis, ANCA-induced (severe) disease reactivation is enabled by or aggravated by an as-yet unidentified factor, or second hit. This hypothesis is substantiated by animal models, in which the priming of neutrophils by bacterial lipopolysaccharide is required for antiproteinase 3 antibody (PR3)-induced alveolar hemorrhage and glomerulonephritis ${ }^{12}$, and aggravates antimyeloperoxidase antibody (MPO)-induced glomerulonephritis ${ }^{13}$. Several candidates for this second hit have been postulated, such as microorganisms ${ }^{14}$, environmental factors ${ }^{15,16}$, and/or other autoantibodies ${ }^{17}$. We hypothesize that Vitamin D may also be important, because it is a major immune-modulating agent ${ }^{18}$. In other autoimmune diseases, such as multiple sclerosis and systemic lupus erythematosus, associations have been observed between low levels of 25-hydroxy Vitamin D $(25(\mathrm{OH}) \mathrm{D})$, the inactive metabolite of Vitamin $\mathrm{D}$, and disease progression or reactivation ${ }^{19,20,21}$. However, the involvement of Vitamin D in AAV has not been elucidated. It has been shown that levels of $25(\mathrm{OH}) \mathrm{D}$ are lower in patients with AAV compared with healthy controls, but no studies have been published concerning the relation between $25(\mathrm{OH}) \mathrm{D}$ and the risk of a relapse in patients with $\mathrm{AAV}^{22}$.

In our current study, we investigated risk factors for a relapse at the time of an ANCA rise to gain insight into potential second hits that are required for disease reactivation. In particular, we focused on seasonal influences, such as $25(\mathrm{OH}) \mathrm{D}$ levels at the time of the ANCA rise and at the time of a subsequent relapse or time-matched during remission.

\section{MATERIALS AND METHODS}

Inclusion criteria for patients. All patients who visited the clinic at the Maastricht University Medical Center between January 1, 2000, and November 1, 2011, were evaluated. Inclusion criteria were a diagnosis of $\mathrm{AAV}^{23}$, previous renal involvement, and a rise in PR3- or MPO-ANCA during remission ${ }^{8}$.

Classification of patients. Patients were subclassified using the European Medicines Agency classification into granulomatosis with polyangiitis (GPA), microscopic polyangiitis (MPA), or eosinophilic GPA (EGPA; Churg-Strauss syndrome), and patients with EGPA were subsequently excluded ${ }^{23,24}$. Renal involvement was preferably determined by a kidney biopsy showing pauciimmune-necrotizing glomerulonephritis ${ }^{25,26}$. However, surrogate markers such as hematuria in combination with red cell casts, dysmorphic erythrocytes $(>10)$, and/or proteinuria sufficed ${ }^{24}$

All patients have been treated according to the European League Against Rheumatism guidelines ${ }^{7,26}$. Regarding the treatment of the previous period with disease activity, we grouped therapy consisting of cyclophosphamide (CYC; oral or intravenous) or rituximab (RTX) as "induction regimen with CYC/RTX." Other therapies [e.g., methotrexate (MTX) or mycophenolate mofetil] were grouped as "induction regimen lacking CYC/RTX." Current immunosuppressive treatment was classified as "immunosuppressive therapy" if the ANCA rise occurred when the patient was treated with any form of immunosuppressive agent or as "no immunosuppressive therapy" if no immunosuppressive therapy was taken. Antibiotic therapy was classified as antibiotic maintenance therapy or as no antibiotic maintenance therapy (short courses of antibiotics were allowed). Patients were defined as persistently ANCA-positive when ANCA values remained positive during followup and as nonpersistently ANCA-positive when an ANCA measurement had at least once been negative. The season during an ANCA rise in the Netherlands is defined as winter during December to February, spring during March to May, summer during June to August, and fall during September to November ${ }^{27}$.

Disease activity state. A relapse was defined as reoccurrence or new onset of disease attributable to active disease combined with an increase or addition of immunosuppressive treatment ${ }^{3,4,8,28,29}$. Relapses were further subdivided into minor or major, depending on whether the relapse was potentially organ- or life-threatening ${ }^{29}$. For a renal relapse, the (re)occurrence of hematuria in combination with a rise in serum creatinine of $25 \%$ was required to be characterized as a major relapse.

Followup. Patients were routinely screened for potential symptoms of a relapse and blood was drawn ${ }^{8}$. Antigen-specific, solid-phase ANCA tests were performed for the detection and quantification of PR3- and MPO-ANCA. Initially, commercially available direct PR3- and MPO-ANCA ELISA were used (Euro Diagnostica) ${ }^{30}$. On October 1, 2005 , this assay was replaced by a fluorescent-enzyme immune-assay (FEIA) for PR3- and MPO-ANCA (EliA, Thermo Fisher) ${ }^{31}$. During the transition, ANCA measurements were performed by both methods.

In addition, ANCA were detected by indirect immunofluorescence (IIF) on ethanol-fixed neutrophil granulocytes (INOVA Diagnostics) ${ }^{31}$. Samples were diluted serially in phosphate buffered saline starting at 1:16.

Clinical characteristics were recorded in all subjects according to the Dutch law on Medical Treatment Act, the Personal Data Protection Act, and the Code of Conduct for Health Research ${ }^{32}$. Ethics approval was waived by our local ethics committee.

Definition of an ANCA rise. For the detection of an ANCA rise, the value was compared to all measurements made with the same assay in the past 6 months. Next to ANCA rises as detected by antigen-specific assays, we additionally investigated ANCA rises as detected by the IIF technique. For the IIF, a rise was defined as a 4 -fold increase ${ }^{2}$. For the antigen-specific, solid-phase assays, we defined a rise using the slope of an increase as previously described ${ }^{8}$, thereby taking into account the relative increase (in \%) and the time between measurements (in days). A receiver-operating characteristics curve was calculated to determine the optimal cutoff value of the slope. The chosen cutoff values as determined by the ELISA and FEIA methods were $2.56 \% /$ day and $2.25 \% /$ day, respectively. This is equivalent to a relative increase of $78 \%$ and $68 \%$ over 1 month or $233 \%$ and $205 \%$ over 3 months. An ANCA increase was defined as an extended rise when the next sample after the ANCA increase continued to rise.

To ensure that small elevations were above the intraassay coefficient of variation, a rise had to constitute to a relative increase of at least $25 \%$ and an absolute increase equivalent to a doubling of the lowest value of a borderline result (at least $10 \mathrm{AU}$ for the ELISA and $5 \mathrm{U} / \mathrm{ml}$ for the FEIA). Because our analysis is focused on patients in remission, only serum samples drawn at least 3 months after the previous disease activity were eligible for detection of an ANCA rise ${ }^{8}$. An ANCA rise was defined as an extended ANCA rise if the next sample was also rising.

Assay of 25(OH)D and serum selection. Quantification of 25(OH)D was performed using the automated LIAISON 25-OH Vitamin D TOTAL assay (DiaSorin). A serum sample was selected at the time of the ANCA rise in all patients. A second sample was selected at the time of the relapse in relapsing patients, or time-matched during remission in patients who remained in remission. If serum was no longer available at the ANCA rise or relapse, a sample 1 month prior or after the ANCA rise or relapse was selected. Circulating 25(OH)D levels above $75 \mathrm{nmol} / \mathrm{l}(30 \mathrm{ng} / \mathrm{ml})$ were considered sufficient, according to international guidelines ${ }^{33}$.

Statistical analysis. Numerical variables were expressed as mean $( \pm \mathrm{SD})$ or median (interquartile range), and categorical variables as numbers $(\%)$. Associations were presented as HR with $95 \%$ CI. A p value $\leq 0.05$ was considered significant. All statistical analyses were performed using

Personal non-commercial use only. The Journal of Rheumatology Copyright @ $\odot 2017$. All rights reserved 
GraphPad Prism version 6.04 for Windows (GraphPad Software) and SPSS statistics for Windows, version 23.0 (IBM).

Differences in baseline patient characteristics were investigated using the chi-square test for categorical variables and the Mann-Whitney U test for continuous variables. Two paired columns were compared using the paired Student $\mathrm{t}$ test. Two unpaired columns were compared with the Mann-Whitney U test.

The time to relapse was estimated using the Kaplan-Meier method. An event was defined as a relapse at the time of the start or increase of immunosuppressive treatment. Subjects were censored at the time of death, last ANCA measurement, or closure of study. Univariate analyses were performed using the log-rank test for categorical variables and a Cox regression model for continuous variables. HR for categorical variables were derived from a Cox regression model. All variables with a $\mathrm{p}$ value $\leq 0.05$ according to the univariate analysis were included in a multivariate analysis using a Cox regression model. The proportional hazards assumption was assessed by Schoenfeld residuals and by visually inspecting log-log plots; variables were included as a time-dependent variable if the assumption was violated.

Several risk factors for a relapse at the time of remission have been described in the literature. However, no analyses have been performed at the time of an ANCA rise. Therefore, several variables were assessed that were thought to be clinically relevant. Included variables were age, sex, diagnosis, ANCA serotype, ENT involvement, Birmingham Vasculitis Activity Score (BVAS; v3), induction regimen at previous disease activity, persistence of ANCA positivity during followup, the time between previous disease activity and the rise, the season in which the rise occurs, the slope of the rise, the value of the rise, whether the rise is extended, 25(OH)D level, current immunosuppressive treatment, antibiotic maintenance therapy, and the existence of a concomitant rise in the IIF titer.

\section{RESULTS}

Patient characteristics and outcome. Sixty patients were included at the time of an ANCA rise (Table 1). Fifty-one patients $(85 \%)$ were PR3-ANCA-positive and 9 patients were MPO-ANCA-positive. Fifty-five patients (91.7\%) had GPA, while the remaining 5 patients had MPA. Thirty-six patients relapsed: 20 major relapses [BVAS 17 (15-19)] and 16 minor relapses [BVAS 7 (4-13)]. Relapses occurred after a median of 6 months (2-13) since the ANCA rise.

Risk factors of a relapse. We observed that a rise during the fall season was highly associated with a relapse (HR 4.37, 95\% CI 1.60-11.90; Figure 1A; see Table 2 for the results of the univariate analysis). Also, 2 other risk factors were significantly associated with a relapse: an induction regimen at previous disease activity lacking CYC or RTX (HR 3.48, 95\% CI 1.60-7.59) and an extended ANCA rise (HR 3.57, 95\% CI 1.50-8.48). All 3 risk factors remained significantly associated with a relapse according to the multivariate analysis (Table 3).

In 13 patients, the ANCA rise occurred during the fall season, of whom $9(69.2 \%)$ and 11 patients $(84.6 \%)$ relapsed within 6 and 12 months, respectively. The proportion of patients who relapsed increased if the next ANCA measurement demonstrated a further rise: 7 of $9(77.8 \%)$ after 6 months and 9 of 9 (100\%) after 12 months (Table 4).

Maintenance therapy. Forty-nine patients were taking immunosuppressive therapy at the time of the ANCA rise, while 11 patients no longer used any immunosuppressive agent at the time of the ANCA rise. Immunosuppressive treatment did not protect patients from a relapse following an ANCA rise $($ chi-square $=1.173, p=0.279$; Figure 1B). In addition, glucocorticoid therapy also did not significantly influence the HR for a relapse after an ANCA rise (Supplementary Data available with the online version of this article).

Thirty-nine of 60 patients were receiving antibiotic maintenance therapy at the time of the ANCA rise. Antibiotic maintenance therapy also did not protect patients from a relapse (chi-square $=0.010, \mathrm{p}=0.922$ ).

Levels of 25-hydroxy Vitamin D. In 58 of 60 patients (97\%), a serum sample was still available at the time of the ANCA rise. Four patients had sufficient levels of $25(\mathrm{OH}) \mathrm{D}$, while 54 had insufficient 25(OH)D levels. At the ANCA rise, there was no difference in $25(\mathrm{OH}) \mathrm{D}$ levels between relapsing patients $(49.5 \pm 16.6 \mathrm{nmol} / \mathrm{l})$ and patients who remained in remission $(45.6 \pm 18.7 \mathrm{nmol} / \mathrm{l}, \mathrm{p}=0.415)$.

Paired samples were available in 57 of 60 patients (95\%). In relapsing patients, the $25(\mathrm{OH}) \mathrm{D}$ level was significantly lower at the time of the relapse compared with the time of the ANCA rise (difference $-6.3 \pm 14.4 \mathrm{nmol} / \mathrm{l}, \mathrm{p}=0.017$; Figure 2A), while the 25(OH)D level was slightly higher during followup in patients who remained in remission after the ANCA rise (difference $2.7 \pm 16.3 \mathrm{nmol} / \mathrm{l}, \mathrm{p}=0.430$; Figure 2B).

\section{DISCUSSION}

In our study, we report risk factors for a relapse at the time of an ANCA rise in patients with renal involvement. Most importantly, we demonstrate that an ANCA rise is most often followed by a relapse when it occurs during the fall season. The level of 25(OH)D significantly decreased after the ANCA rise in relapsing patients, but not in patients who remained in remission.

Several theories have been postulated on the relationship between ANCA and disease reactivation. An ANCA rise may be directly pathogenic. This is unlikely, however, because fewer than half of the patients in whom an ANCA rise occurs will relapse within a year. Therefore, a second hit is probably required $^{5,13}$. In a mouse model of MPO-ANCA, it has been demonstrated that proinflammatory stimuli of infectious origin and ANCA act synergistically to induce glomerulonephritis ${ }^{13}$. Our finding that an ANCA rise occurring during the fall season is more often followed by a relapse is in accordance with this hypothesis, because patients in the Netherlands are at increased risk of a respiratory tract infection during the following months ${ }^{34}$. However, we did not systematically score for infections during followup. Therefore, no objective arguments of an infection were systematically obtained.

Interestingly, however, antibiotic maintenance therapy does not protect against a relapse after an ANCA rise in our current study. This contrasts with previous observations,

Personal non-commercial use only. The Journal of Rheumatology Copyright (c) 2017. All rights reserved. 
Table 1. Patient characteristics. Values are median (interquartile range) or as the $\mathrm{n}(\%)$.

\begin{tabular}{|c|c|c|c|}
\hline Characteristics & Relapse, $\mathrm{n}=36$ & Remission, $\mathrm{n}=24$ & $\mathrm{p}$ \\
\hline Age, yrs & $57.0(43.5-21.0)$ & $55.5(51.3-62.0)$ & 0.934 \\
\hline Female & $12(33.3)$ & $9(37.5)$ & 0.740 \\
\hline PR3-ANCA & $31(86.1)$ & $20(83.3)$ & 0.768 \\
\hline BVAS v3 & $18.5(13.3-21.0)$ & $18.5(14.0-23.8)$ & 0.281 \\
\hline GPA & $33(91.7)$ & $22(91.7)$ & 1.000 \\
\hline MPA & $3(8.3)$ & $2(8.3)$ & 1.000 \\
\hline \multicolumn{4}{|l|}{ Previous organ involvement } \\
\hline Arthralgia & $21(58.3)$ & $13(54.2)$ & 0.750 \\
\hline Cutaneous & $15(41.7)$ & $5(20.8)$ & 0.094 \\
\hline Eyes & $8(22.2)$ & $5(20.8)$ & 0.898 \\
\hline ENT & $28(77.8)$ & $20(83.3)$ & 0.598 \\
\hline Lung & $25(69.4)$ & $17(70.8)$ & 0.908 \\
\hline Cardiovascular & $1(2.8)$ & $3(12.5)$ & 0.139 \\
\hline Renal & $36(100)$ & $24(100)$ & - \\
\hline Abdominal & $2(5.6)$ & $3(12.5)$ & 0.340 \\
\hline Central nervous system & $1(2.8)$ & $0(0)$ & 0.410 \\
\hline Peripheral nervous system & $7(19.4)$ & $4(16.7)$ & 0.785 \\
\hline \multicolumn{4}{|l|}{ Therapy } \\
\hline Induction regimen with $\mathrm{CYC} / \mathrm{RTX}$ & $23(63.9)$ & $21(87.5)$ & 0.043 \\
\hline Current immunosuppressive therapy & $31(86.1)$ & $18(75.0)$ & 0.276 \\
\hline Antibiotics maintenance therapy & $23(63.9)$ & $16(66.7)$ & 0.825 \\
\hline \multicolumn{4}{|l|}{ ANCA rise } \\
\hline Time since previous disease activity, mos & $16.0(8.5-25.8)$ & $13.0(9.5-27.3)$ & 0.701 \\
\hline Slope of the rise, $\%$ increase per day & $8.8(4.6-15.9)$ & $4.9(3.4-10.3)$ & 0.763 \\
\hline Value at the rise & $37.5(21.3-61.8)$ & $31.5(21.0-48.5)$ & 0.970 \\
\hline Concomitant IIF rise & $32(88.9)$ & $21(87.5)$ & 0.870 \\
\hline Extended rise & $28(77.8)$ & $8(33.3)$ & 0.001 \\
\hline Season & & & 0.028 \\
\hline Winter & $9(25.0)$ & $2(8.3)$ & \\
\hline Spring & $7(19.4)$ & $9(37.5)$ & \\
\hline Summer & $9(25.0)$ & $11(45.8)$ & \\
\hline Fall & $11(30.6)$ & $2(8.3)$ & \\
\hline \multicolumn{4}{|l|}{ Followup } \\
\hline Persistently positive & $12(33.3)$ & $9(37.5)$ & 0.740 \\
\hline
\end{tabular}

Significant data are in bold face. ANCA: antineutrophil cytoplasmic antibodies; PR3-ANCA: proteinase 3 ANCA; BVAS: Birmingham Vasculitis Activity Score; GPA: granulomatosis with polyangiitis; MPA: microscopic polyangiitis; CYC: cyclophosphamide; RTX: rituximab; IIF: indirect immunofluorescence.

because it has been shown that cotrimoxazole maintenance therapy is protective of a relapse ${ }^{35}$. There may be several reasons for this. First, in the study by Stegeman, et al, a high dose of cotrimoxazole ( $960 \mathrm{mg}$ twice daily) was given, while this was not always the case in our patients ${ }^{35}$. Second, patients who did not receive antibiotic maintenance therapy were advised to take a short course of antibiotics as soon as symptoms of a possible infection occurred. Third, the antibiotic agent that is taken during antibiotic maintenance therapy may not cover all relevant infections. Therefore, no firm conclusion can be drawn on the influence of antibiotics on the risk of a relapse after an ANCA rise.

Another important seasonal factor is Vitamin D. At the latitude of the Netherlands, the nadir of Vitamin D occurs during the end of the winter, while the level of Vitamin D is at its highest at the end of summer ${ }^{36}$. It is known that Vitamin $\mathrm{D}$ is an important immune-modulating agent ${ }^{18}$. In vitro studies have shown that Vitamin D skews immune cells toward a more tolerogenic status ${ }^{18}$. For instance, the proliferation of B cells, an important cell in the pathophysiology of AAV, was inhibited by the active metabolite of Vitamin D $\left(1,25\right.$-dihydroxy Vitamin D) in experimental studies ${ }^{37}$. In vivo, however, the interactions between Vitamin D metabolites and B cells seem to be more complex ${ }^{38}$. Importantly, associations with disease reactivation have previously been observed in other autoimmune diseases, but not in $\mathrm{AAV}^{19,20,21}$. We demonstrate that a reduction of $25(\mathrm{OH}) \mathrm{D}$ upon an ANCA rise is associated with the development of a relapse in AAV. This decrease in patients who will relapse was to be expected, because these patients more often have an ANCA rise during the fall season. Therefore, their levels of $25(\mathrm{OH}) \mathrm{D}$ will decrease during the upcoming months according to the seasonal variation of $25(\mathrm{OH}) \mathrm{D}$. However, it is questionable whether the observed changes in Vitamin D are biologically significant. Also, no firm conclusions can yet be drawn concerning the causality of this association. We 
(A) Time to relapse after an ANCA rise according to season

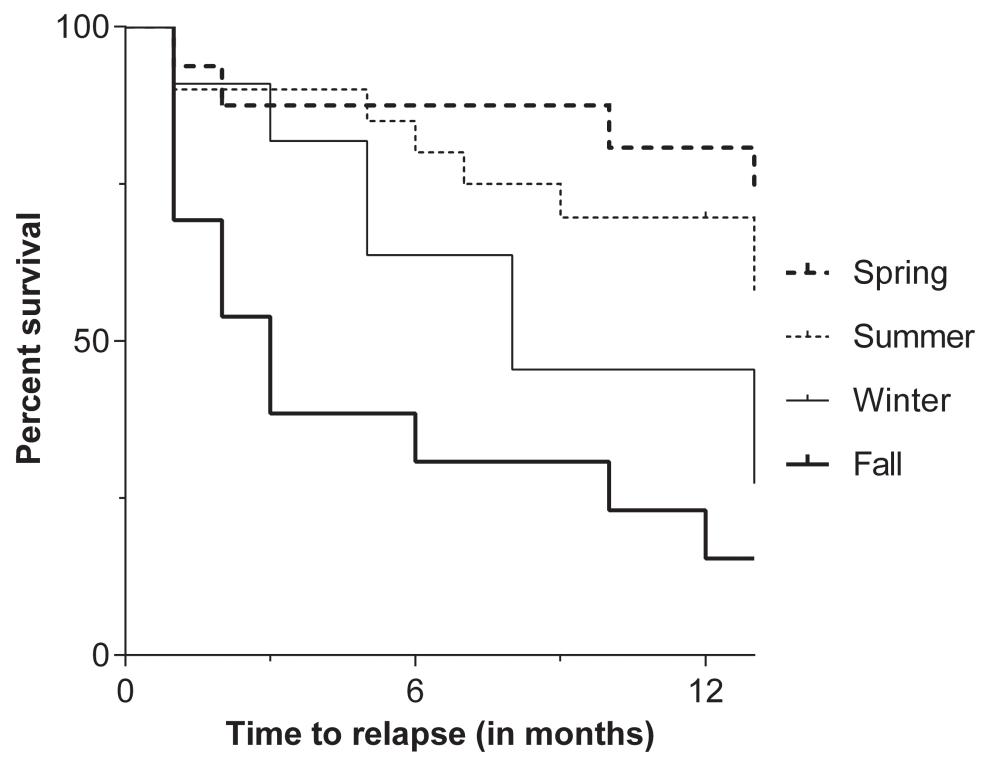

(B) Time to relapse according to current immunosuppressive therapy

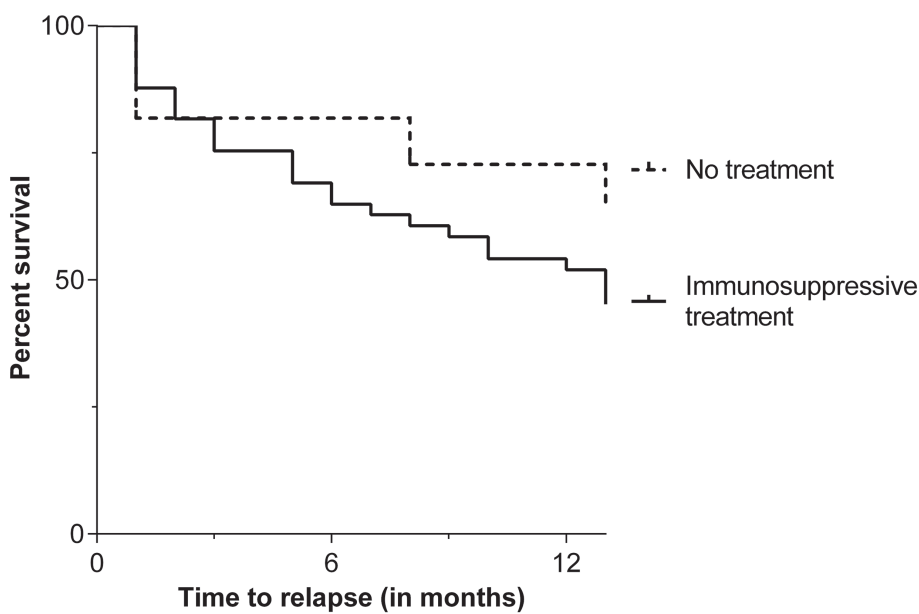

Figure 1. Time to relapse after an ANCA rise according to (A) season (chi-square $=12.383, \mathrm{p}=$ 0.006 ) and (B) current immunosuppressive therapy (chi-square $=1.173, \mathrm{p}=0.279$ ). ANCA: antineutrophil cytoplasmic antibodies.

conclude that patients with AAV may in particular benefit from Vitamin D supplementation during the fall and winter to prevent a disease relapse.

While the quantity of the autoantibody may be important, other factors may be involved ${ }^{5}$. For instance, epitope specificity, avidity, and the sialylation level of ANCA may contribute to the risk of developing a relapse after an ANCA rise $^{39,40}$. Therefore, further research on the association between the quality of ANCA at the time of an ANCA rise and disease activity is warranted.

Changes in ANCA level may be related to changes in immunosuppressive treatment ${ }^{41}$. Importantly, we found that a similar number of patients relapsed after an ANCA rise regardless of whether they were receiving immunosuppressive therapy. We found, however, that patients who were treated during the previous disease activity period with an immunosuppressive regimen lacking CYC or RTX relapsed more often than patients who were treated during the previous disease activity period with CYC or RTX. This finding adds to the growing body of data that suggests that a milder treatment modality, such as MTX, induces a less-stable remission compared with CYC or $\mathrm{RTX}^{42}$.

Our study has several limitations ${ }^{8}$. In our current retrospective study, physicians were not blinded to ANCA results $^{2,3}$. Our cohort was mostly composed of PR3-ANCApositive patients; therefore, our findings may not apply to

Personal non-commercial use only. The Journal of Rheumatology Copyright (C) 2017. All rights reserved. 
Table 2. Results of the univariate analysis of risk factors for a relapse from the time of an ANCA rise. Differences were assessed using the log-rank test for categorical variables and a Cox regression model for continuous variables.

\begin{tabular}{|c|c|c|c|c|c|}
\hline \multirow[t]{2}{*}{ Univariate Analysis } & \multicolumn{2}{|c|}{ Cox Regression } & \multicolumn{3}{|c|}{ Log-rank } \\
\hline & HR & $95 \% \mathrm{CI}$ & $\mathrm{p}$ & Chi-square & $\mathrm{p}$ \\
\hline Age & 1.00 & $0.97-1.02$ & 0.997 & - & - \\
\hline Male & 1.12 & $0.55-2.22$ & - & 0.084 & 0.772 \\
\hline MPO-ANCA & 0.92 & $0.57-1.49$ & - & 0.118 & 0.732 \\
\hline ENT involvement & 0.62 & $0.28-1.36$ & - & 1.546 & 0.214 \\
\hline BVAS v3 & 0.96 & $0.91-1.01$ & 0.122 & - & - \\
\hline GPA & 0.98 & $0.29-3.35$ & - & 0.001 & 0.977 \\
\hline \multicolumn{6}{|l|}{ Therapy } \\
\hline Induction regimen with $\mathrm{CYC} / \mathrm{RTX}$ & 0.33 & $0.16-0.68$ & - & 10.708 & 0.001 \\
\hline Current immunosuppressive therapy & 1.66 & $0.64-4.30$ & - & 1.173 & 0.279 \\
\hline Antibiotic maintenance therapy & 0.99 & $0.83-1.18$ & - & 0.010 & 0.922 \\
\hline \multicolumn{6}{|l|}{ Followup } \\
\hline Previously ANCA-negative & 1.21 & $0.85-1.73$ & - & 1.158 & 0.282 \\
\hline \multicolumn{6}{|l|}{ ANCA rise } \\
\hline Time since previous disease activity, mos & 1.00 & $0.98-1.02$ & 0.717 & - & - \\
\hline Slope of the rise & 1.00 & $1.00-1.01$ & 0.933 & - & - \\
\hline ANCA value at rise & 1.00 & $1.00-1.00$ & 0.903 & - & - \\
\hline Concomitant IIF rise & 0.99 & $0.35-2.80$ & - & 0.001 & 0.979 \\
\hline Extended rise & 2.70 & $1.22-5.96$ & - & 6.862 & 0.009 \\
\hline Season & & & & 12.383 & 0.006 \\
\hline Spring & Reference & & & & \\
\hline Summer & 1.16 & $0.43-3.11$ & - & & \\
\hline Fall & 3.95 & $1.50-10.36$ & - & & \\
\hline Winter & 2.10 & $0.75-5.83$ & - & & \\
\hline \multicolumn{6}{|l|}{ 25-hydroxy Vitamin D } \\
\hline Vitamin D, continuous variable & 1.01 & $0.99-1.03$ & 0.377 & - & - \\
\hline Hypovitaminosis $\mathrm{D}, \leq 75 \mathrm{nmol} / \mathrm{l}$ & 1.39 & $0.33-5.84$ & - & 0.215 & 0.643 \\
\hline
\end{tabular}

Significant data are in bold face. ANCA: antineutrophil cytoplasmic antibodies; MPO-ANCA: myeloperoxidase ANCA; BVAS: Birmingham Vasculitis Activity Score; GPA: granulomatosis with polyangiitis; CYC: cyclophosphamide; RTX: rituximab; IIF: indirect immunofluorescence.

Table 3. Results of the multivariate analysis of risk factors for a relapse from the time of a rise in antineutrophil cytoplasmic antibodies.

\begin{tabular}{lccc}
\hline \multirow{2}{*}{ Risk Factors } & \multicolumn{2}{c}{ Multivariate } & $\mathrm{p}$ \\
& HR & $95 \% \mathrm{CI}$ & \\
\hline Induction regimen lacking & & & \\
$\quad$ CYC/RTX & 3.48 & $1.60-7.59$ & $\mathbf{0 . 0 0 2}$ \\
Extended rise & 3.57 & $1.50-8.48$ & $\mathbf{0 . 0 0 4}$ \\
Season & & & \\
$\quad$ Spring & Reference & & \\
$\quad$ Summer & 2.24 & $0.79-6.33$ & 0.128 \\
$\quad$ Fall & 4.37 & $1.60-11.90$ & $\mathbf{0 . 0 0 4}$ \\
$\quad$ Winter & 1.82 & $0.64-5.17$ & 0.260 \\
\hline
\end{tabular}

Significant data are in bold face. CYC: cyclophosphamide; RTX: rituximab.

MPO-ANCA-positive patients. This also holds true for patients with MPA because the majority of our patients had GPA. We have no solid data on the usage of Vitamin D supplements by our patients, because these supplements are readily accessible over the counter. Vitamin D supplementation $(500 \mathrm{mg} / 800 \mathrm{IE})$ is prescribed to all patients who receive prednisone with a dosage higher than $7.5 \mathrm{mg}$ per day for a period longer than 3 months. No data are available on the vaccination status of our patients, although no increased risk for a relapse was previously observed following a vaccination ${ }^{43}$. Importantly, we verified that risk factors were specifically associated with both major relapses and minor relapses, as well as renal and nonrenal relapses (Supplementary Data, available with the online version of this article). Our current study is low powered and the lack of precision of our results is obvious in the $95 \% \mathrm{CI}$ around the estimated HR. This limitation is most evident when only major or renal relapses are studied, as highlighted by the broad 95\% CI (Supplementary Data, available with the online version of this article). Yet our findings are significant in a small single-center study and warrant further research in a large, prospective, multicenter study. Genuine and important risk factors may have been missed because of the inadequate power of our study. The risk factors of the relapse identified in our study need to be replicated in more rigorous larger studies in the future. Results from small studies may be affected by a few outliers. We identified 2 outliers who relapsed a very long period after the ANCA rise (73 and 95 mos). However, exclusion of these patients did not change the results (data not shown).

We identified risk factors for a relapse at the time of an 
Table 4. The proportion of relapsing patients within 6 and 12 months since the ANCA rise by number and type of risk factor.

\begin{tabular}{|c|c|c|c|c|c|}
\hline & \multicolumn{2}{|c|}{ Risk Factors } & \multirow[b]{2}{*}{$\begin{array}{l}\text { Extended } \\
\text { ANCA Rise }\end{array}$} & \multicolumn{2}{|c|}{ No. Patients Who Relapse after ANCA Rise } \\
\hline & Fall Season & $\begin{array}{l}\text { Induction Regimen } \\
\text { Lacking CYC/RTX }\end{array}$ & & $6 \mathrm{Mos}$ & $12 \mathrm{Mos}$ \\
\hline Total cohort & - & - & - & 16 of $60(31.7 \%)$ & 26 of $60(43.3 \%)$ \\
\hline \multirow[t]{3}{*}{ One risk factor } & Yes & - & - & 9 of $13(69.2 \%)$ & 11 of $13(84.6 \%)$ \\
\hline & - & Yes & - & 8 of $16(50.0 \%)$ & 11 of $16(68.8 \%)$ \\
\hline & - & - & Yes & 14 of $36(38.9 \%)$ & 20 of $36(55.6 \%)$ \\
\hline \multirow[t]{3}{*}{ Two risk factors } & Yes & Yes & - & 4 of $5(80.0 \%)$ & 5 of $5(100 \%)$ \\
\hline & Yes & - & Yes & 7 of $9(77.8 \%)$ & 9 of $9(100 \%)$ \\
\hline & - & Yes & Yes & 6 of $9(66.7 \%)$ & 8 of $9(88.9 \%)$ \\
\hline Three risk factors & Yes & Yes & Yes & 2 of $3(66.7 \%)$ & 3 of $3(100 \%)$ \\
\hline
\end{tabular}

ANCA: antineutrophil cytoplasmic antibodies; CYC: cyclophosphamide; RTX: rituximab.

\section{(A) Vitamin D levels in relapsing patients}

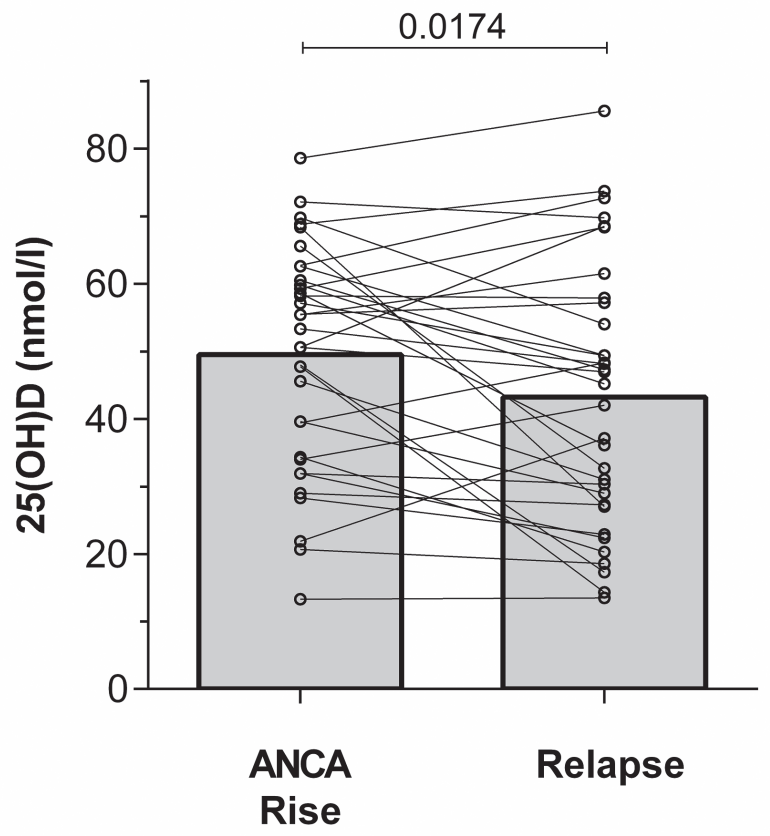

\section{(B) Vitamin D levels in patients who remain in remission}

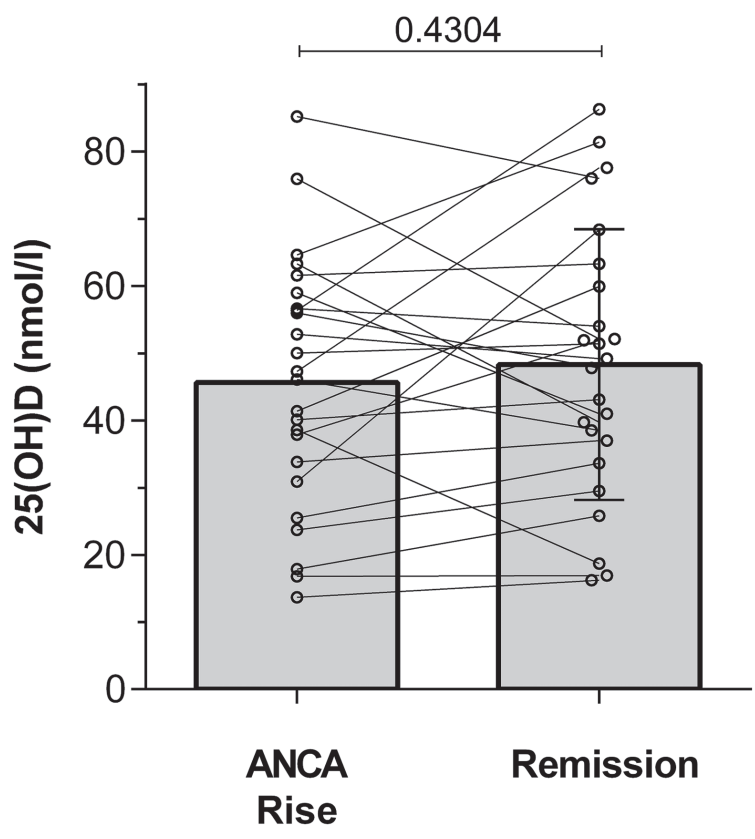

Figure 2. Level of 25(OH)D during followup in (A) patients who relapse after the ANCA rise and (B) patients who remain in remission after the ANCA rise. 25(OH)D: 25-hydroxy Vitamin D; ANCA: antineutrophil cytoplasmic antibodies.

ANCA rise in patients with renal involvement. In particular, an ANCA rise occurring in the fall season is an important risk factor for a relapse. We postulate that a subsequent decrease in Vitamin D level may enable proinflammatory skewing of the immune system and can therefore in part be held responsible for this phenomenon. The influence of other factors, such as intercurrent infections and the quality of ANCA on the risk for a relapse after an ANCA rise, should be prospectively studied.

\section{ONLINE SUPPLEMENT}

Supplementary material accompanies the online version of this article.

\section{REFERENCES}

1. Wilde B, van Paassen P, Witzke O, Tervaert JW. New pathophysiological insights and treatment of ANCA-associated vasculitis. Kidney Int 2011;79:599-612.

2. Tervaert JW, van der Woude FJ, Fauci AS, Ambrus JL, Velosa J, Keane WF, et al. Association between active Wegener's granulomatosis and anticytoplasmic antibodies. Arch Intern Med 1989;149:2461-5.

\section{Personal non-commercial use only. The Journal of Rheumatology Copyright $@$ $~ 2017$. All rights reserved}


3. Boomsma MM, Stegeman CA, Van Der Leij MJ, Oost W, Hermans $\mathrm{J}$, Kallenberg CG, et al. Prediction of relapses in Wegener's granulomatosis by measurement of antineutrophil cytoplasmic antibody levels: a prospective study. Arthritis Rheum 2000; 43:2025-33.

4. Tervaert JW, Huitema MG, Hené RJ, Sluiter WJ, The TH, van der Hem GK, et al. Prevention of relapses in Wegener's granulomatosis by treatment based on antineutrophil cytoplasmic antibody titre. Lancet 1990;336:709-11.

5. Cohen Tervaert JW, Damoiseaux J. Antineutrophil cytoplasmic autoantibodies: how are they detected and what is their use for diagnosis, classification and follow-up? Clin Rev Allergy Immunol 2012;43:211-9.

6. Tomasson G, Grayson PC, Mahr AD, LaValley M, Merkel PA. Value of ANCA measurements during remission to predict a relapse of ANCA-associated vasculitis - a meta-analysis. Rheumatology 2012;51:100-9.

7. Mukhtyar C, Guillevin L, Cid MC, Dasgupta B, de Groot K, Gross W, et al; European Vasculitis Study Group. EULAR recommendations for the management of primary small and medium vessel vasculitis. Ann Rheum Dis 2009;68:310-7.

8. Kemna MJ, Damoiseaux J, Austen J, Winkens B, Peters J, van Paassen $\mathrm{P}$, et al. ANCA as a predictor of relapse: useful in patients with renal involvement but not in patients with nonrenal disease. J Am Soc Nephrol 2015;26:537-42.

9. Nölle B, Specks U, Ludemann J, Rohrbach MS, DeRemee RA, Gross WL. Anticytoplasmic autoantibodies: their immunodiagnostic value in Wegener granulomatosis. Ann Intern Med 1989;111:28-40.

10. Birck R, Schmitt WH, Kaelsch IA, van der Woude FJ. Serial ANCA determinations for monitoring disease activity in patients with ANCA-associated vasculitis: systematic review. Am J Kidney Dis 2006; 47:15-23.

11. Chen M, Kallenberg CG, Zhao MH. ANCA-negative pauci-immune crescentic glomerulonephritis. Nat Rev Nephrol 2009;5:313-8.

12. Little MA, Al-Ani B, Ren S, Al-Nuaimi H, Leite M Jr, Alpers CE, et al. Anti-proteinase 3 anti-neutrophil cytoplasm autoantibodies recapitulate systemic vasculitis in mice with a humanized immune system. PLoS ONE 2012;7:e28626.

13. Huugen D, Xiao H, van Esch A, Falk RJ, Peutz-Kootstra CJ, Buurman WA, et al. Aggravation of anti-myeloperoxidase antibody-induced glomerulonephritis by bacterial lipopolysaccharide: role of tumor necrosis factor-alpha. Am J Pathol 2005; $167: 47-58$

14. Popa ER, Stegeman CA, Kallenberg CG, Tervaert J. Staphylococcus aureus and Wegener's granulomatosis. Arthritis Res 2002;4:77-9.

15. Gatenby PA, Lucas RM, Engelsen O, Ponsonby AL, Clements M. Antineutrophil cytoplasmic antibody-associated vasculitides: could geographic patterns be explained by ambient ultraviolet radiation? Arthritis Rheum 2009;61:1417-24.

16. de Lind van Wijngaarden RA, van Rijn L, Hagen EC, Watts RA, Gregorini G, Tervaert JW, et al. Hypotheses on the etiology of antineutrophil cytoplasmic autoantibody associated vasculitis: the cause is hidden, but the result is known. Clin J Am Soc Nephrol 2008;3:237-52.

17. Kain R, Tadema H, McKinney EF, Benharkou A, Brandes R, Peschel A, et al. High prevalence of autoantibodies to hLAMP-2 in anti-neutrophil cytoplasmic antibody-associated vasculitis. J Am Soc Nephrol 2012;23:556-66.

18. Peelen E, Knippenberg S, Muris AH, Thewissen M, Smolders J, Tervaert JW, et al. Effects of vitamin D on the peripheral adaptive immune system: a review. Autoimmun Rev 2011;10:733-43.

19. Dall'Ara F, Andreoli L, Piva N, Piantoni S, Franceschini F, Tincani A. Winter lupus flares are associated with low vitamin D levels in a retrospective longitudinal study of Italian adult patients. Clin Exp Rheumatol 2015;33:153-8.
20. Birmingham DJ, Hebert LA, Song H, Noonan WT, Rovin BH, Nagaraja HN, et al. Evidence that abnormally large seasonal declines in vitamin D status may trigger SLE flare in non-African Americans. Lupus 2012;21:855-64.

21. Ascherio A, Munger KL, White R, Köchert K, Simon KC, Polman $\mathrm{CH}$, et al. Vitamin $\mathrm{D}$ as an early predictor of multiple sclerosis activity and progression. JAMA Neurol 2014;71:306-14.

22. Kälsch AI, Peters A, Buhl B, Breedijk A, Prem K, Schmitt WH, et al. Retinoid $X$ receptor beta polymorphisms do not explain functional differences in vitamins $\mathrm{D}$ and A response in antineutrophil cytoplasmic antibody associated vasculitis patients. Autoimmunity 2009;42:467-74.

23. Jennette JC, Falk RJ, Bacon PA, Basu N, Cid MC, Ferrario F, et al 2012 revised International Chapel Hill Consensus Conference Nomenclature of Vasculitides. Arthritis Rheum 2013;65:1-11.

24. Watts R, Lane S, Hanslik T, Hauser T, Hellmich B, Koldingsnes W, et al. Development and validation of a consensus methodology for the classification of the ANCA-associated vasculitides and polyarteritis nodosa for epidemiological studies. Ann Rheum Dis 2007;66:222-7

25. Berden AE, Ferrario F, Hagen EC, Jayne DR, Jennette JC, Joh K, et al. Histopathologic classification of ANCA-associated glomerulonephritis. J Am Soc Nephrol 2010;21:1628-36.

26. Hilhorst M, Wilde B, van Breda Vriesman P, van Paassen P, Cohen Tervaert JW; Limburg Renal Registry. Estimating renal survival using the ANCA-associated GN classification. J Am Soc Nephrol 2013;24:1371-5.

27. Koninklijk Nederlands Meteorologisch Instituut (KNMI). Seizoenen. [Internet. Accessed January 4, 2017.] Available from: www.knmi.nl/kennis-en-datacentrum/uitleg/seizoenen

28. Slot MC, Tervaert JW, Boomsma MM, Stegeman CA. Positive classic antineutrophil cytoplasmic antibody (C-ANCA) titer at switch to azathioprine therapy associated with relapse in proteinase 3-related vasculitis. Arthritis Rheum 2004;51:269-73.

29. Hellmich B, Flossmann O, Gross WL, Bacon P, Cohen-Tervaert JW, Guillevin L, et al. EULAR recommendations for conducting clinical studies and/or clinical trials in systemic vasculitis: focus on anti-neutrophil cytoplasm antibody-associated vasculitis. Ann Rheum Dis 2007;66:605-17.

30. Boomsma MM, Damoiseaux JG, Stegeman CA, Kallenberg CG, Patnaik M, Peter JB, et al. Image analysis: a novel approach for the quantification of antineutrophil cytoplasmic antibody levels in patients with Wegener's granulomatosis. J Immunol Methods 2003;274:27-35.

31. Damoiseaux JG, Slot MC, Vaessen M, Stegeman CA, Van Paassen $\mathrm{P}$, Tervaert JW. Evaluation of a new fluorescent-enzyme immuno-assay for diagnosis and follow-up of ANCA-associated vasculitis. J Clin Immunol 2005;25:202-8.

32. Central Committee on Research Involving Human Subjects. Non-WMO research. [Internet. Accessed January 4, 2017.] Available from: www.ccmo.nl/en/non-wmo-research

33. Holick MF, Binkley NC, Bischoff-Ferrari HA, Gordon CM, Hanley DA, Heaney RP, et al; Endocrine Society. Evaluation, treatment, and prevention of vitamin D deficiency: an Endocrine Society clinical practice guideline. J Clin Endocrinol Metab 2011; 96:1911-30.

34. National Institute for Public Health and the Environment: Ministry of Health, Welfare and Sport. State of infectious disease in the Netherlands 2012. [Internet. Accessed January 5, 2017.] Available from: www.rivm.nl/bibliotheek/rapporten/150002002.pdf

35. Stegeman CA, Tervaert JW, de Jong PE, Kallenberg CG. Trimethoprim-sulfamethoxazole (co-trimoxazole) for the prevention of relapses of Wegener's granulomatosis. Dutch Co-Trimoxazole Wegener Study Group. N Engl J Med 1996;335:16-20.

36. Hyppönen E, Power C. Hypovitaminosis D in British adults at age 
$45 \mathrm{y}$ : nationwide cohort study of dietary and lifestyle predictors. Am J Clin Nutr 2007;85:860-8.

37. Chen S, Sims GP, Chen XX, Gu YY, Chen S, Lipsky PE.

Modulatory effects of 1,25-dihydroxyvitamin D3 on human B cell differentiation. J Immunol 2007;179:1634-47.

38. Rolf L, Muris AH, Hupperts R, Damoiseaux J. Illuminating vitamin D effects on B cells - the multiple sclerosis perspective. Immunology 2016;147:275-84

39. Espy C, Morelle W, Kavian N, Grange P, Goulvestre C, Viallon V, et al. Sialylation levels of anti-proteinase 3 antibodies are associated with the activity of granulomatosis with polyangiitis (Wegener's). Arthritis Rheum 2011;63:2105-15.

40. Roth AJ, Ooi JD, Hess JJ, van Timmeren MM, Berg EA, Poulton $\mathrm{CE}$, et al. Epitope specificity determines pathogenicity and detectability in ANCA-associated vasculitis. J Clin Invest 2013;123:1773-83.
41. Rasmussen N, Salmela A, Ekstrand A, de Groot K, Gregorini G, Cohen Tervaert JW, et al. Changes in proteinase 3 anti-neutrophil cytoplasm autoantibody levels in early systemic granulomatosis with polyangiitis (Wegener's) may reflect treatment rather than disease activity. Clin Exp Rheumatol 2013;31 Suppl 75:S38-44.

42. Faurschou M, Westman K, Rasmussen N, de Groot K, Flossmann O, Höglund $\mathrm{P}$, et al. Brief report: long-term outcome of a randomized clinical trial comparing methotrexate to cyclophosphamide for remission induction in early systemic antineutrophil cytoplasmic antibody-associated vasculitis. Arthritis Rheum 2012;64:3472-7.

43. Stassen PM, Sanders JS, Kallenberg CG, Stegeman CA. Influenza vaccination does not result in an increase in relapses in patients with ANCA-associated vasculitis. Nephrol Dial Transplant 2008; 23:654-8. 